\title{
Effects of barium on the pathways of anaerobic digestion
}

\author{
V. Wyman ${ }^{a, b}$, A. Serrano*c,d, R. Borja ${ }^{c}$, A. Jiménez ${ }^{\text {b }}$, A. Carvajala, M. Lenz ${ }^{\text {e,f }}$, J. \\ Bartacek $^{\mathrm{g}}$, F. G. Fermoso ${ }^{\mathrm{c}}$
}

${ }^{a}$ Universidad Técnica Federico Santa María, Avenida Vicuña Mackenna 3939 San Joaquín, Santiago, Chile.

${ }^{\mathrm{b}}$ Universidad Pablo de Olavide, Carretera de Utrera, 1, 41013 Seville, Spain

${ }^{\mathrm{c}}$ Instituto de la Grasa (CSIC), Seville, Spain

d School of Civil Engineering, The University of Queensland, Ed. 49, Campus St Lucia, 4067, Brisbane, Australia

${ }^{\mathrm{e}}$ Institute for Ecopreneurship, School of Life Sciences, University of Applied Sciences and Arts Northwestern Switzerland, Switzerland

${ }^{\mathrm{f}}$ Sub-Department of Environmental Technology, Wageningen University, 6700 AA Wageningen, The Netherlands

${ }^{\mathrm{g}}$ University of Chemistry and Technology Prague, Czech

*Corresponding author: Tel.: +61 (07) 3365 3857; E-mail: a.serranomoral@uq.edu.au

\begin{abstract}
The sufficient presence of trace elements (TE) is essential for anaerobic digestion. Barium $(\mathrm{Ba})$ is considered a non-essential trace element that can be collaterally added to digesters as part of low-cost trace element sources or because of its presence in some feedstocks, such as crude glycerol. In the present study, the impact of $\mathrm{Ba}$ supplementation $(2-2,000 \mathrm{mg} / \mathrm{L})$ on each stage of the anaerobic digestion (AD) process was evaluated using pure substrates (i.e., cellulose, glucose, a mixture of volatile fatty acids, sodium acetate and hydrogen) as well as a complex substrate (i.e., dried green
\end{abstract}


fodder). Hydrolytic activity was affected at dosages higher than $200 \mathrm{mg} \mathrm{Ba} / \mathrm{L}$, whereas cellulose degradation was completely inhibited at 2,000 mg Ba/L. The negative effects of the addition of $\mathrm{Ba}$ to methane production were observed only in the hydrolytic activity, and no effects were detected at any barium dosage in the subsequent anaerobic steps. Because Ba does not have a reported role as a cofactor of enzymes, this response could have been due to a direct inhibitory effect, a variation in the bioavailability of other trace elements, or even the availability of $\mathrm{CO}_{2} / \mathrm{SO}_{4}$ through precipitation as Bacarbonates and sulphates. The results showed that the addition of Ba modified the chemical equilibrium of the studied system by varying the soluble concentration of some TEs and therefore their bioavailability. The highest variation was detected in the soluble concentration of zinc, which increased as the amount of $\mathrm{Ba}$ increased. Although little research has shown that $\mathrm{Ba}$ has some utility in anaerobic processes, its addition must be carefully monitored to avoid an undesirable modification of the chemical equilibrium in the system.

Keywords: Hydrolysis; trace elements; metal bioavailability; trace element dosing

\section{INTRODUCTION}

Anaerobic digestion (AD) constitutes an effective technology for organic waste treatment, management and valorisation through energy generation and fertiliser production. The AD process is carried out by microorganisms having an anoxic metabolism that degrades organic matter, ultimately releasing methane $\left(\mathrm{CH}_{4}\right)$, carbon dioxide $\left(\mathrm{CO}_{2}\right)$ and other minor components. $\mathrm{AD}$ consists of four main stages: hydrolysis, acidogenesis, acetogenesis and methanogenesis (Appels et al., 2008; Merlin Christy et al., 2014). 
Many studies have been carried out to understand the limiting factors of single groups of microorganisms that catalyse each stage in order to improve the cost and efficiency of AD (Merlin Christy et al., 2014). The adequate presence and availability of trace elements (TE) in enzymatic cofactors and metalloenzymes are prerequisites for the latter (Choong et al., 2016; Thanh et al., 2016). TE can be either stimulatory or inhibitory, and its imbalance may cause instability and even the complete failure of AD (Fermoso et al., 2008a).

In particular, several elements, such as iron (Fe), nickel (Ni), cobalt $(\mathrm{Co})$, cupper $(\mathrm{Cu})$, zinc $(\mathrm{Zn})$, molybdenum (Mo) and/or selenium (Se), have been reported to be essential in different stages of AD (Fermoso et al., 2008b; Gustavsson et al., 2013; Schmidt et al., 2014; Thanh et al., 2016; Worm et al., 2009). In consequence, supplementation with such elements has been shown to improve AD performance using different substrates (Choong et al., 2016). The addition of these elements was related to a decrease in volatile fatty acids (VFA) and a consequent increase in the biogas production rate and biogas yield (Nordell et al., 2016). In contrast, several studies found that inhibition and toxicity were attributed to the excess of TE (Bartacek et al., 2008; Chen et al., 2008; Pinto-Ibieta et al., 2016). Because of the complex pathways involved in $\mathrm{AD}$, several studies examined the effects of TE on each step of $\mathrm{AD}$ (Fermoso et al., 2008a; Pinto-Ibieta et al., 2016). For example, Co was notably involved in the last (methanogenic) step. The importance of Co is related to its presence in $\mathrm{CO}$ dehydrogenase and methyl-H4MPT:HS-CoM methyltransferase, which are enzymes involved in methanogenesis from acetate (Ferry, 1999; Pinto-Ibieta et al., 2016). Other TEs, such as $\mathrm{Ni}, \mathrm{Zn}, \mathrm{Mg}$ and $\mathrm{Mn}$, have been reported to show important activity as metalloenzymes that catalyse hydrolytic reactions (Bertini and Luchinat, 1994). Despite their presence as cofactors, some elements may also exert further indirect effects. For 
instance, the high presence of Fe increased methane yield when agricultural waste is used as a substrate, which was attributed to the capacity of its alkali treatment to break the cellulose structure (Cai et al., 2017).

For obvious reasons, non-essential TEs have not been studied as direct micronutrients in AD. However, the presence of some non-essential TEs may have effects on $\mathrm{AD}$. Barium $(\mathrm{Ba})$ is an element that belongs to the IIA group. It appears to be the least studied of the heavier alkali and alkaline earth metals in terms of its functionally in replacing elements in biological systems (Wackett et al., 2004). The presence of $\mathrm{Ba}$ in an anaerobic system could be related to its content in industrial wastewater, such as crude glycerol (Danilović et al., 2017). Furthermore, the purposeful addition of fly ash as low-cost source of TE to anaerobic systems may entail the collateral supplementation of Ba (Gertner et al., 2017; Montalvo et al., 2017). A recent study showed that hydrolytic enzymes were stimulated in the presence of Ba (Muñoz et al., 2016), whereas the mechanism remained unresolved. Many authors have reported that the concept of bioavailability is the key factor in the effects of trace metals. In fact, $\mathrm{Ba}$ has been used to enhance sulphate removal by precipitation as sulphates such as Barite (Navamani Kartic et al., 2018). Consequently, the addition of Ba may have a beneficial effect through the decreased formation of highly inhibitory sulphide, which is the metabolic end-product of sulphate reducers). However, the addition of Ba may negatively affect the substrate availability of the system because it may promote carbonate formation (e.g., Witherite); $\mathrm{CO}_{2}$ is the substrate for hydrogenotrophs. To date, it has not been clearly shown how $\mathrm{Ba}$ affects $\mathrm{AD}$ or at which concentration the effects are beneficial or detrimental.

Therefore, the aim of this work was to study the influence of different concentrations of $\mathrm{Ba}$ dosage on different stages of $\mathrm{AD}$ using simple substrates (i.e., 
cellulose, glucose, a mixture of volatile fatty acids, sodium acetate and hydrogen) and a real complex substrate (i.e., dried green fodder).

\section{MATERIALS AND METHODS}

\subsection{Anaerobic inoculum and substrates}

Anaerobic inoculum was obtained from the wastewater treatment plant of a brewery company located in Seville, Spain. The inoculum was concentrated by sedimentation before characterisation (Table 1). To determine the effect of Ba supplementation on AD, different synthetic substrates were used to simulate each stage of the process. The stages of hydrolysis, acidogenesis, acetogenesis, acetoclastic methanogenesis and hydrogenotrophic methanogenesis were evaluated using cellulose (cellulose microcrystalline colloidal, Sigma Aldrich), glucose $(\mathrm{D}(+)$-glucose anhydrous $\geq 99.5 \%$, Panreac), a mix of short chain acids (propionic $\left(\mathrm{C}_{3} \mathrm{H}_{6} \mathrm{O}_{6}\right)$, butyric $\left(\mathrm{C}_{4} \mathrm{H}_{8} \mathrm{O}_{2}\right)$ and valeric $\left(\mathrm{C}_{5} \mathrm{H}_{10} \mathrm{O}_{2}\right)$, Sigma Aldrich), sodium acetate (sodium acetate anhydrous, Sigma Aldrich) and hydrogen $\left(\mathrm{H}_{2}\right.$, SIAD Czech spol. s r.o.), respectively. The influence of the $\mathrm{Ba}$ conversion of a real complex substrate was evaluated by its addition to dried green fodder (DGF) (particle size $<355 \mu \mathrm{m}$ ). The main characteristics of the synthetic substrates and the DGF are shown in Table 1.

\subsection{Biochemical methane potential assays}

Biochemical methane potential (BMP) assays were performed in triplicate using different Ba supplementation doses on synthetic and DGF substrates. Ba was dosed as barium chloride dihydrate $\left(\mathrm{BaCl}_{2} \cdot 2 \mathrm{H}_{2} \mathrm{O}\right.$ extra pure Sigma Aldrich) at concentrations of 2, 20, 200 and 2,000 $\mathrm{mg} \mathrm{Ba} / \mathrm{L}$ in the working volume of BMP assays $(220 \mathrm{~mL})$. In addition, the experimental design considered triplicates of BMP assays at $0 \mathrm{mg} \mathrm{Ba} / \mathrm{L}$ (control) and without substrate (blank). The BMP assays were carried out until the 
methane production was exhausted. At the end of the experiments, the liquid digestate of the BMP assays was characterised.

\subsubsection{BMP assays: hydrolysis, acidogenesis, acetogenesis and acetoclastic} methanogenesis stages

The BMP assays were performed in batch mode using a continuously stirred system in flasks of $250 \mathrm{~mL}$. Temperature conditions were maintained at $35 \pm 1{ }^{\circ} \mathrm{C}$ through a heated water bath. Methane production was quantified by soda volume displacement using soda $2 \mathrm{~N}$ in all experiments. A buffer solution of $\mathrm{NaHCO}_{3} 0.068 \mathrm{M}$ (Holliger et al., 2016) and a micro-macronutrients solution (Table 2) (Angelidaki et al., 2009) were added. A glucose solution of $0.54 \mathrm{mM}$ was added for sludge conditioning 24 hours before the substrates and Ba supplementation were added (Holliger et al., 2016). The air content in the system was displaced by nitrogen at the beginning of the assays to ensure anaerobic conditions.

The experiments were performed using substrate/inoculum ratios (measured in grams of total volatile solids) of $0.8,0.3,0.3,0.3$ and 0.5 for cellulose, glucose, mix of short chain acids (VFA), sodium acetate and DGF, respectively. The different substrate/inoculum ratios were selected to avoid the acidification of the process because of the easy biodegradability of the synthetic substrates.

\subsubsection{BMP assays: hydrogenotrophic methanogenesis stage}

The BMP assays were carried out using Pyrex ${ }^{\circledR}$ bottles of $500 \mathrm{~mL}$ as reactors. The temperature was maintained constant at $36 \pm 1{ }^{\circ} \mathrm{C}$ in a temperature-controlled room. The methane production was quantified by chromatography. As in the other experiments, a buffer solution of $\mathrm{NaHCO}_{3}$ and a micro-macronutrient solution were added. The concentration of the buffer solution was higher than in the other cases because it was used as a source of carbon dioxide. The sludge was conditioned for 24 hours using a 
solution $0.54 \mathrm{mM}$ glucose. The headspace of the reactors $(420 \mathrm{~mL})$ was flushed with nitrogen to remove the oxygen and then filled with hydrogen to overpressure up to 30 $\mathrm{kPa}$.

\subsection{Analytical techniques}

The characterisation of the anaerobic inoculum and substrates as well as the characterisation of the samples at the end of the BMP assays were carried out according to the analytical techniques described below. Contents of total solids (TS g/kg), volatile solids (VS g/kg), alkalinity ( $\left.\mathrm{mg} \mathrm{CaCO}_{3} / \mathrm{L}\right)$ and $\mathrm{pH}$ were performed using standard methods (American Public Health Association [APHA], 2005). The soluble chemical oxygen demand ( $\mathrm{sCOD} \mathrm{mgO}_{2} / \mathrm{L}$ ) was measured by spectrophotometry at $600 \mathrm{~nm}$ after reaction with potassium dichromate (Raposo et al., 2008).

In the experiments carried out to evaluate the hydrogenotrophic methanogenesis stage, the decrease in pressure combined with the changes in gas composition were used to calculate the consumption of hydrogen. The biogas quality was measured using a GC-TCD (CE Instruments GC 8000 Top, Wigan, UK) equipped with a packed column (Porapak Q 80-100 mesh, Waters Corporation, Milford, Massachusetts, USA). Subsequently, the decrease in pressure combined with the changes in gas composition were used to calculate the share of hydrogen.

At the end of all BMP assays, the liquid phase was analysed to measure the concentration of dissolved metals. The liquid phase samples were prepared under anoxic conditions, filtered using $0.22 \mu \mathrm{m}$ pore size and then fixed in a solution with a final concentration of 3\% nitric acid ( $\mathrm{HNO}_{3} 65 \%$ semiconductor grade, Sigma Aldrich). Total metal concentrations in the inoculum and the substrates were also measured after the addition of nitric acid $\left(\mathrm{HNO}_{3} 65 \%\right.$ semiconductor grade, Sigma Aldrich). The analysis was performed using an 8800 qqq-ICP-MS system (Agilent, Basel, 
Switzerland) with general-purpose operational settings. Quantification was performed using multi-element standards (Sigma Aldrich). Rh was used as internal standard to account for the matrix effects. To quantify ${ }^{63} \mathrm{Cu}^{+},{ }^{66} \mathrm{Zn}^{+},{ }^{95} \mathrm{Mo}^{+}$and ${ }^{135} \mathrm{Ba}^{+}$, the ICP-MS was operated in single quad mode using helium as a collision gas, whereas $\mathrm{Fe}, \mathrm{Co}, \mathrm{Ni}$ and Se were measured in triple quad mass-shift mode using $\mathrm{O}_{2}$ as the reaction gas (as ${ }^{56} \mathrm{Fe}^{16} \mathrm{O}^{+},{ }^{59} \mathrm{Co}^{16} \mathrm{O}^{+},{ }^{60} \mathrm{Ni}^{16} \mathrm{O}^{+}$and $\left.{ }^{80} \mathrm{Se}^{16} \mathrm{O}^{+}\right)$.

\subsection{Kinetic model}

The kinetics parameters were determined by applying a non-linear regression approach using SigmaPlot ${ }^{\mathrm{TM}}$ version 11 (Systat Software). The experimental data fit with the transfer function (TF), equation 1 (Parra-Orobio et al., 2017). The application of the TF was previously reported in batch-mode biomethanisation processes of several organic substrates (Donoso-Bravo et al., 2010; Pinto-Ibieta et al., 2016; Wyman et al., 2017).

$$
\mathrm{V}_{\mathrm{cH}_{4}}(\mathrm{t})=G_{\max }\left(1-\exp \left(\frac{-R_{\max }(t-\lambda)}{\mathrm{G}_{\max }}\right)\right)(\text { Equation } 1)
$$

where $V_{\mathrm{CH}_{4}}$ is the accumulated methane yield (mLstP/gVS); $G_{\text {max }}$ is the maximum methane yield (mLsTP $/ \mathrm{gVS}) ; R_{\max }$ is the maximum methane production rate (mLsTP $/(\mathrm{gVSd}))$; and $\lambda$ is the lag phase period $(d)$. All results are presented as average values and standard deviations at standard temperature and pressure (STP) conditions: 273.15 $\mathrm{K}$ and $101.33 \mathrm{kPa}$ (Holliger et al., 2016).

\section{RESULTS AND DISCUSSION}

\subsection{Effects of Ba on methane production}

\subsubsection{Effects of Ba on methanogenesis, acetogenesis and acidogenesis stages}

The effects of $\mathrm{Ba}$ dosages on the accumulated methane production of acetoclastic methanogenesis (acetate), hydrogenotrophic methanogenesis $\left(\mathrm{H}_{2}\right)$, 
acetogenesis (mix of short chain acids) and acidogenesis (glucose) stages are shown in Figure 1. In the acetoclastic methanogenesis stage (Figure 1A), it was observed that the maximum methane production was slightly decreased at Ba dosages of 200 and 2,000 mg Ba/L. The methane production using $\mathrm{H}_{2}$ and $\mathrm{CO}_{2}$ (hydrogenotrophic methanogenesis) did not show any inhibitory effect (Figure 2B). The acetogenesis and acidogenesis stages (Figure 1C and 1D) showed similar final methane yields in all the cases studied, varying in a short range from $313 \pm 20$ to $309 \pm 10\left(\mathrm{mLsTP}_{\mathrm{CH}} / \mathrm{g}\right.$ COD$)$, respectively.

The obtained coefficient values of the methane yield were close to the theoretical maximum methane yield coefficient of $350 \mathrm{mLsTP} \mathrm{CH}_{4} / \mathrm{g}$ COD. The $\mathrm{Ba}$ doses did not result in an effect over the maximum methane yield coefficient. The trace metals that were mainly involved in these steps were Co and Ni (Gustavsson et al., 2013; Thanh et al., 2016), the concentrations of which did not increase as a consequence of the $\mathrm{Ba}$ addition (Table 3 ).

The effluents from the acetogenesis and acidogenesis assays showed $\mathrm{pH}$ values (Table 4) within the optimal range described for the anaerobic process: 7.1-7.7 (Wheatley, 1990). The assays in the methanogenesis step assays showed a $\mathrm{pH}$ slightly higher than those described as optimal, and the alkalinity values were higher than those obtained in the acetogenesis and acidogenesis assays (Table 4). These alkalinity values could be explained by the extra alkalinity provided by the synthetic substrate used, which was sodium acetate. However, the $\mathrm{pH}$ measured in the effluents of the assays carried out with hydrogen was around 9.1 (Table 4). This increase should not be attributed to the presence of $\mathrm{Ba}$ but to the excess of the $\mathrm{NaHCO}_{3}$ added as a source of carbon dioxide. 
The biodegradability values, which were measured as percentages of theoretical methane production from the total COD were in accordance with the high methane yield coefficient values described previously, reaching values higher than $83 \%$ in all cases. The high biodegradability was expected because of the use of readily digestible synthetic substrates. The COD values obtained oscillated between $105 \pm 2$ to $172 \pm 5$ $\mathrm{mg} \mathrm{O}_{2} / \mathrm{L}$ (Table 4), indicating that the soluble organic matter decreased during the experimental period.

\subsubsection{Effects of $\mathrm{Ba}$ on the hydrolysis stage}

The hydrolytic step was evaluated through the anaerobic digestion of cellulose as a simple synthetic substrate and DGF as complex real substrate. Figures $2 \mathrm{~A}$ and $2 \mathrm{~B}$ show the accumulated methane production in the cellulose and DGF assays at different doses of $\mathrm{Ba}$. In both cases, the methane yield coefficient was sensitive to the presence of different $\mathrm{Ba}$ concentrations. Regarding the cellulose, the assay with the highest $(2,000$ ppm) concentration of $\mathrm{Ba}$ showed total inhibition, whereas the $\mathrm{Ba}$ dosages between 0 to $200 \mathrm{mg} / \mathrm{L}$ resulted in a mean methane yield coefficient of $264 \pm 8 \mathrm{mLsTP} \mathrm{CH}_{4} / \mathrm{g} \mathrm{COD}$ (Figure 2A).

In the case of DGF, the methane yield coefficient slightly increased at dosages of 2 and $20 \mathrm{mg} \mathrm{Ba} / \mathrm{L}$, compared to the assay without the Ba addition (Figure 2B). This enhancement could not be explained because $\mathrm{Ba}$ is not an essential element. Because the methanogenic, acetogenic, acidogenic and cellulosic activities were not improved by the addition of $\mathrm{Ba}$, it could be hypothesised that the enhancement of the methane yield coefficient could be the consequence of the improved activity of other hydrolytic enzymes. Ba dosages higher than $200 \mathrm{mg} / \mathrm{L}$ resulted in a decrease in the methane yield coefficient (Figure 2B). Regarding the complex substrate, DGF, the addition of 2,000 $\mathrm{mg} \mathrm{Ba} / \mathrm{L}$ did not result in the total inhibition of the methane production which was in 
contrast to the results of the cellulose assays. This difference could be attributed to the complexity of the DGF, the biodegradation of which implied different hydrolytic pathways as well as the release of soluble compounds from the raw substrate that were easily methanised to avoid the hydrolysis stage.

As observed in the other stages of the $\mathrm{AD}$ process, the $\mathrm{pH}$ and alkalinity values obtained at the end of the experiments (Table 5) did not vary as the amount of Ba was increased. The values were close to the optimal range in the anaerobic metabolism and activity (Wheatley, 1990). However, in the hydrolysis stage, the biodegradability showed clear differences. In the case of the cellulose, the biodegradability was around $75.5 \pm 2.2 \%$ at $0,2,20$ and $200 \mathrm{mg} \mathrm{Ba} / \mathrm{L}$, whereas total inhibition occurred at 2,000 $\mathrm{mg}$ $\mathrm{Ba} / \mathrm{L}$. In the case of the DGF, the biodegradability values increased from $64.0 \pm 4.1 \%$ at no $\mathrm{Ba}$ dosage to $75.1 \pm 1.2 \%$ at $20 \mathrm{mg} \mathrm{Ba} / \mathrm{L}$. The values then decreased to $57.9 \pm 2.4 \%$ at $200 \mathrm{mg} \mathrm{Ba} / \mathrm{L}$ and $54.4 \pm 0.1 \%$ at $2,000 \mathrm{mg} \mathrm{Ba} / \mathrm{L}$ (Table 5). These sequential effects could be a consequence of the different sensitivities of the involved hydrolytic enzymes to the modifications of the chemical equilibrium and the bioavailability of TE by the addition of Ba.

The sCOD values obtained from the effluents of the digesters used to study the hydrolysis stage (Table 5) were around four times higher than those obtained in the other stages (Table 4). This behaviour could be explained by the complexity of the evaluated substrates. The highest sCOD values, around $920 \mathrm{mg} \mathrm{O}_{2} / \mathrm{L}$, were reached in the experiments using cellulose. In the DGF substrate, the values were around $416 \mathrm{mg}$ $\mathrm{O}_{2} / \mathrm{L}$, indicating the higher degradation of soluble organic matter than in cellulose.

To compare the evolution of the methane production during the biomethanisation of DGF, the experimental data shown in Figure 3B were adjusted to the transfer function model (Table 6). As shown in Table 6, Gmax presented values 
similar to the experimental methane yield coefficients. Differences were shown between the theoretical and experimental values lower than $4.2 \%$ in all cases. These values showed that Ba concentrations from 0 to $20 \mathrm{mg} / \mathrm{L}$ did not entail variation in $R_{\max }$, which showed a mean value of $7.2 \pm 0.4 \mathrm{mLsTP} \mathrm{CH}_{4} /(\mathrm{g}$ VS $\cdot \mathrm{d})$ (Table 6). However, at dosages of 200 and $2,000 \mathrm{mg} \mathrm{Ba} / \mathrm{L}$, a marked drop in $R_{\max }$ values was observed, which were $23 \%$ and $35 \%$ lower, respectively, than in the assays performed without the addition of Ba (Table 6).

\subsection{Effects of Ba on the final concentrations of soluble metals}

Because $\mathrm{Ba}$ has not been reported to be a cofactor of enzymes involved in the AD process, the inhibition could be an indirect effect of the modification of the chemical equilibrium of other metals. The increasing Ba doses affected, to differing extents, the concentrations of the measured dissolved metals (Table 3). Most of the measured dissolved metals did not show any clear variation due to the addition of $\mathrm{Ba}$ except dissolved $\mathrm{Ba}$ and, to a lesser extent, dissolved $\mathrm{Zn}$. Specifically, the $\mathrm{Cu}$ concentration varied widely from $2.49 \pm 0.05$ to $170 \pm 2.9 \mu \mathrm{g} / \mathrm{L}$ (Table 3 ) with values lower than those reported as inhibitory, that is, from 70-400 mg/L (Karri et al., 2006). The determined variation in $\mathrm{Cu}$ concentrations did not follow a clear trend with the addition of $\mathrm{Ba}$. It was not possible to establish any trend between $\mathrm{Co}, \mathrm{Ni}$ and $\mathrm{Fe}$ concentrations against the $\mathrm{Ba}$ added to the assays (Table 3 ). In fact, the $\mathrm{Co}$ and $\mathrm{Ni}$ concentrations remained virtually constant in the differently measured samples. The measured range of concentrations of $\mathrm{Co}, \mathrm{Ni}$ and $\mathrm{Fe}$ were within the required dissolved concentrations for each trace metal for anaerobic digestion: 5-22 $\mu \mathrm{g} / \mathrm{L}$ for $\mathrm{Co}, 8-146$ $\mu \mathrm{g} / \mathrm{L}$ for $\mathrm{Ni}$, and 0.3-8.3 mg/L for Fe (Choong et al., 2016; Matheri et al., 2016).

The concentration of dissolved $\mathrm{Zn}$ was increased by the addition of $\mathrm{Ba}$ (Table 3), showing a linear relation between the soluble $\mathrm{Ba}$ concentration and soluble $\mathrm{Zn}$ up to 
values of around 1,000-1,200 $\mu \mathrm{g} / \mathrm{L}$ (Figure 3). As shown in Table 3, the soluble Zn was lower than $0.2 \mathrm{mg} / \mathrm{L}$ in the reactors with low Ba supplementation $(<20 \mathrm{mg} \mathrm{Ba} / \mathrm{L})$. However, from $200 \mathrm{mg} \mathrm{Ba} / \mathrm{L}$, the variation in soluble $\mathrm{Zn}$ was increased more than 10 times compared to the other conditions (Table 3). It should be noted that because its input was measured as lower than $1 \%$, the $\mathrm{Zn}$ concentration present in the Ba reagent as an impurity (Table 1) did not contribute to the final $\mathrm{Zn}$ concentration reported in the effluents.

Several studies reported that $\mathrm{Zn}$ is an essential element because of its participation as a cofactor in more than 300 enzymes (Zastrow and Pecoraro, 2014). For example, $\mathrm{Zn}$ participates significantly in the formation of metalloenzymes catalysing hydrolytic reactions (Bertini and Luchinat, 1994). Inhibition by Zn might occur in concentrations as low as $0.6 \mathrm{mg} / \mathrm{L}$ (Lo et al., 2007). Therefore, the addition of 2,000 $\mathrm{mg}$ $\mathrm{Ba} / \mathrm{L}$ resulted in the increase in soluble $\mathrm{Zn}$ concentrations up to potentially toxic levels (Figure 3 and Table 3). Hence, it is possible to hypothesise that $\mathrm{Zn}$ could be the main inhibition agent because its concentration was above some previously reported inhibition concentrations (Lo et al., 2007).

\section{CONCLUSIONS}

The presence of $\mathrm{Ba}$ affected the anaerobic digestion pathways although these effects seemed to be indirect. The addition of Ba modified the chemical equilibrium of the studied system by varying the soluble concentrations of some TEs and therefore their bioavailability. The highest variation was detected in the soluble concentration of $\mathrm{Zn}$, which increased as the amount of $\mathrm{Ba}$ increased. Hydrolytic activity was affected at $\mathrm{Ba}$ dosages higher than $200 \mathrm{mg} / \mathrm{L}$, whereas cellulose degradation was completed inhibited at $\mathrm{Ba}$ dosages of $2,000 \mathrm{mg} / \mathrm{L}$. The effects of the Ba addition were only on the hydrolytic 
activity, and no effects were detected at any $\mathrm{Ba}$ dosage in the subsequent anaerobic steps. The determined inhibitory effects could be a consequence of a disturbance in the chemical equilibrium caused by the Ba supplementation instead of the direct effect of the $\mathrm{Ba}$. Although responses were observed at high Ba concentrations, the knowledge of the role of $\mathrm{Ba}$ is important in contributing to the understanding of the $\mathrm{AD}$ process and the dynamics of chemical equilibrium in the anaerobic system. Similarly, although the addition of $\mathrm{Ba}$ has been reported to have some utility in anaerobic processes, its addition must be carefully monitored to avoid the undesirable modification of the chemical equilibrium of the system.

\section{ACKNOWLEDGEMENTS}

This work was supported by the Asociación Universitaria Iberoamericana de Postgrado through the call Programa de Becas de Movilidad entre Universidades Andaluzas e Iberoamericanas 2017. The authors are also very grateful to the Spanish Ministry of Economy and Competitiveness or funding this research through the project CTM2017-83870-R, as well as to the COST Action ES1302 for funding a Short Term Scientific Mission (STSM).

\section{REFERENCES}

American Public Health Association (APHA), 2005. Standard Methods for the Examination of Water and Wastewater, Standard Methods.

Angelidaki, I., Alves, M., Bolzonella, D., Borzacconi, L., Campos, J.L., Guwy, A.J., Kalyuzhnyi, S., Jenicek, P., Van Lier, J.B., 2009. Defining the biomethane potential (BMP) of solid organic wastes and energy crops: A proposed protocol for batch assays. Water Sci. Technol. 59, 927-934. doi:10.2166/wst.2009.040 
Appels, L., Baeyens, J., Degrève, J., Dewil, R., 2008. Principles and potential of the anaerobic digestion of waste-activated sludge. Prog. Energy Combust. Sci. 34, 755781. doi:10.1016/j.pecs.2008.06.002

Bartacek, J., Fermoso, F.G., Baldó-Urrutia, A.M., Van Hullebusch, E.D., Lens, P.N.L., 2008. Cobalt toxicity in anaerobic granular sludge: Influence of chemical speciation. J. Ind. Microbiol. Biotechnol. 35, 1465-1474. doi:10.1007/s10295-008-0448-0

Bertini, I., Luchinat, C., 1994. The Reaction Pathways of Zinc Enzymes and Related Biological Catalysts. Bioinorg. Chem. 37-106.

Cai, Y., Hua, B., Gao, L., Hu, Y., Yuan, X., Cui, Z., Zhu, W., Wang, X., 2017. Effects of adding trace elements on rice straw anaerobic mono-digestion: Focus on changes in microbial communities using high-throughput sequencing. Bioresour. Technol. 239, 454-463. doi:10.1016/j.biortech.2017.04.071

Chen, Y., Cheng, J.J., Creamer, K.S., 2008. Inhibition of anaerobic digestion process: A review. Bioresour. Technol. 99, 4044-4064. doi:10.1016/j.biortech.2007.01.057

Choong, Y.Y., Norli, I., Abdullah, A.Z., Yhaya, M.F., 2016. Impacts of trace element supplementation on the performance of anaerobic digestion process: A critical review. Bioresour. Technol. 209, 369-379. doi:10.1016/j.biortech.2016.03.028

Danilović, J., Deutsch, L., Magerl, U., Savić, D., Kolbl, S., Stres, B., 2017. The impact of crude glycerol from biodiesel production on biomethane production and trace metal content in batch experiment, in: Fermoso, F. G., Serrano, A. (Ed.), 1st International Congress on Metals in Anaerobic Biotechnologies (IMAB). Events4u, Seville, pp. 90-91. doi:978-84-6 97-6301-8

Donoso-Bravo, A., Pérez-Elvira, S.I., Fdz-Polanco, F., 2010. Application of simplified models for anaerobic biodegradability tests. Evaluation of pre-treatment processes. Chem. Eng. J. 160, 607-614. doi:10.1016/j.cej.2010.03.082 
Fermoso, F.G., Collins, G., Bartacek, J., O’Flaherty, V., Lens, P., 2008a. Acidification of methanol-fed anaerobic granular sludge bioreactors by cobalt deprivation: Induction and microbial community dynamics. Biotechnol. Bioeng. 99, 49-58. doi:10.1002/bit.21528

Fermoso, F.G., Collins, G., Bartacek, J., O’Flaherty, V., Lens, P., 2008b. Role of nickel in high rate methanol degradation in anaerobic granular sludge bioreactors. Biodegradation 19, 725-737. doi:10.1007/s10532-008-9177-3

Ferry, J.G., 1999. Enzymology of one-carbon metabolism in methanogenic pathways. FEMS Microbiol. Rev. doi:10.1016/S0168-6445(98)00029-1

Gertner, P., Huiliñir, C., Pinto-Villegas, P., Castillo, A., Montalvo, S., Guerrero, L., 2017. A new model for including the effect of fly ash on biochemical methane potential. Waste Manag. 68, 232-239. doi:10.1016/j.wasman.2017.07.005

Gustavsson, J., Shakeri Yekta, S., Sundberg, C., Karlsson, A., Ejlertsson, J., Skyllberg, U., Svensson, B.H., 2013. Bioavailability of cobalt and nickel during anaerobic digestion of sulfur-rich stillage for biogas formation. Appl. Energy 112, 473-477. doi:10.1016/j.apenergy.2013.02.009

Holliger, C., Alves, M., Andrade, D., Angelidaki, I., Astals, S., Baier, U., Bougrier, C., Buffiere, P., Carballa, M., de Wilde, V., Ebertseder, F., Fernandez, B., Ficara, E., Fotidis, I., Frigon, J.-C., de Laclos, H.F., Ghasimi, D.S.M., Hack, G., Hartel, M., Heerenklage, J., Horvath, I.S., Jenicek, P., Koch, K., Krautwald, J., Lizasoain, J., Liu, J., Mosberger, L., Nistor, M., Oechsner, H., Oliveira, J. V., Paterson, M., Pauss, A., Pommier, S., Porqueddu, I., Raposo, F., Ribeiro, T., Rusch Pfund, F., Stromberg, S., Torrijos, M., van Eekert, M., van Lier, J., Wedwitschka, H., Wierinck, I., 2016. Towards a standardization of biomethane potential tests. Water Sci. Technol. 1-9. doi:10.2166/wst.2016.336 
Karri, S., Sierra-Alvarez, R., Field, J.A., 2006. Toxicity of copper to acetoclastic and hydrogenotrophic activities of methanogens and sulfate reducers in anaerobic sludge. Chemosphere 62, 121-127. doi:10.1016/j.chemosphere.2005.04.016

Lo, H.M., Liu, M.H., Chiu, H.Y., Liao, Y.L., Wu, K.C., Hsieh, C.Y., Hsu, H.S., 2007. The effects of $\mathrm{Cd}, \mathrm{Cr}, \mathrm{Ni}$ and $\mathrm{Zn}$ on MSW anaerobic digestion, in: 100th Annual Conference and Exhibition of the Air and Waste Management Association 2007, ACE 2007.

Matheri, A.N., Belaid, M., Seodigeng, T., Ngila, J.C., 2016. The role of trace elements on anaerobic co-digestion in biogas production. Lect. Notes Eng. Comput. Sci. 2224.

Merlin Christy, P., Gopinath, L.R., Divya, D., 2014. A review on anaerobic decomposition and enhancement of biogas production through enzymes and microorganisms. Renew. Sustain. Energy Rev. 34, 167-173. doi:10.1016/j.rser.2014.03.010

Montalvo, S., Cahn, I., Borja, R., Huiliñir, C., Guerrero, L., 2017. Use of solid residue from thermal power plant (fly ash) for enhancing sewage sludge anaerobic digestion: Influence of fly ash particle size. Bioresour. Technol. 244, 416-422. doi:10.1016/j.biortech.2017.07.159

Mudhoo, A., Kumar, S., 2013. Effects of heavy metals as stress factors on anaerobic digestion processes and biogas production from biomass. Int. J. Environ. Sci. Technol. 10, 1383-1398. doi:10.1007/s13762-012-0167-y

Muñoz, C., Fermoso, F.G., Rivas, M., Gonzalez, J.M., 2016. Hydrolytic enzyme activity enhanced by Barium supplementation. AIMS Microbiol. 2, 402-411. doi:10.3934/microbiol.2016.4.402

Navamani Kartic, D., Aditya Narayana, B.C., Arivazhagan, M., 2018. Removal of high concentration of sulfate from pigment industry effluent by chemical precipitation 
using barium chloride: RSM and ANN modeling approach. J. Environ. Manage. 206, 69-76. doi:10.1016/j.jenvman.2017.10.017

Nordell, E., Nilsson, B., Nilsson P??ledal, S., Karisalmi, K., Moestedt, J., 2016. Codigestion of manure and industrial waste - The effects of trace element addition. Waste Manag. 47, 21-27. doi:10.1016/j.wasman.2015.02.032

Parra-orobio, B.A., Donoso-bravo, A., Torres-lozada, P., 2017. Anaerobic digestion of food waste . Predicting of methane production by comparing kinetic models Digestión anaerobia de residuos de alimentos . Predicción de la producción de metano mediante la comparación de modelos cinéticos 210-218.

Pinto-Ibieta, F., Serrano, A., Jeison, D., Borja, R., Fermoso, F.G., 2016. Effect of cobalt supplementation and fractionation on the biological response in the biomethanization of Olive Mill Solid Waste. Bioresour. Technol. 211, 58-64. doi:10.1016/j.biortech.2016.03.031

Raposo, F., de la Rubia, M.A., Borja, R., Alaiz, M., 2008. Assessment of a modified and optimised method for determining chemical oxygen demand of solid substrates and solutions with high suspended solid content. Talanta 76, 448-453. doi:10.1016/j.talanta.2008.03.030

Schmidt, T., Nelles, M., Scholwin, F., Pröter, J., 2014. Trace element supplementation in the biogas production from wheat stillage - Optimization of metal dosing. Bioresour. Technol. 168, 80-85. doi:10.1016/j.biortech.2014.02.124

Thanh, P.M., Ketheesan, B., Yan, Z., Stuckey, D., 2016. Trace metal speciation and bioavailability in anaerobic digestion: A review. Biotechnol. Adv. 34, 122-136. doi:10.1016/j.biotechadv.2015.12.006

Wackett, L.P., Dodge, A.G., Lynda, B.M., Ellis, L.B.M., 2004. Microbial Genomics and the Periodic Table MINIREVIEW Microbial Genomics and the Periodic Table. 
Appl. Environ. Microbiol. 70, 647-655. doi:10.1128/AEM.70.2.647

Wheatley, A. (Society of C.I., 1990. Anaerobic digestion : a waste treatment technology. London : Elsevier Applied Science, cop. 1990, London.

Worm, P., Fermoso, F.G., Lens, P.N.L., Plugge, C.M., 2009. Decreased activity of a propionate degrading community in a UASB reactor fed with synthetic medium without molybdenum, tungsten and selenium. Enzyme Microb. Technol. 45, 139145. doi:10.1016/j.enzmictec.2009.02.001

Wyman, V., Henríquez, J., Palma, C., Carvajal, A., 2017. Lignocellulosic waste valorisation strategy through enzyme and biogas production. Bioresour. Technol. doi:10.1016/j.biortech.2017.09.055

Zastrow, M.L., Pecoraro, V.L., 2014. Designing hydrolytic zinc metalloenzymes. Biochemistry 53, 957-978. doi:10.1021/bi4016617 


\section{FIGURE CAPTIONS}

Figure 1. Accumulated methane yield obtained for synthetic substrates: (a) sodium acetate, (b) hydrogen, (c) mix of short chain acids, (d) glucose

Figure 2. Accumulated methane yield obtained for (a) cellulose and (b) dried green fodder (DGF).

Figure 3. Soluble $\mathrm{Zn}$ and $\mathrm{Ba}$ concentration detected in the effluent of the BMP assays using cellulose as a substrate. 
Figure 1.

A)

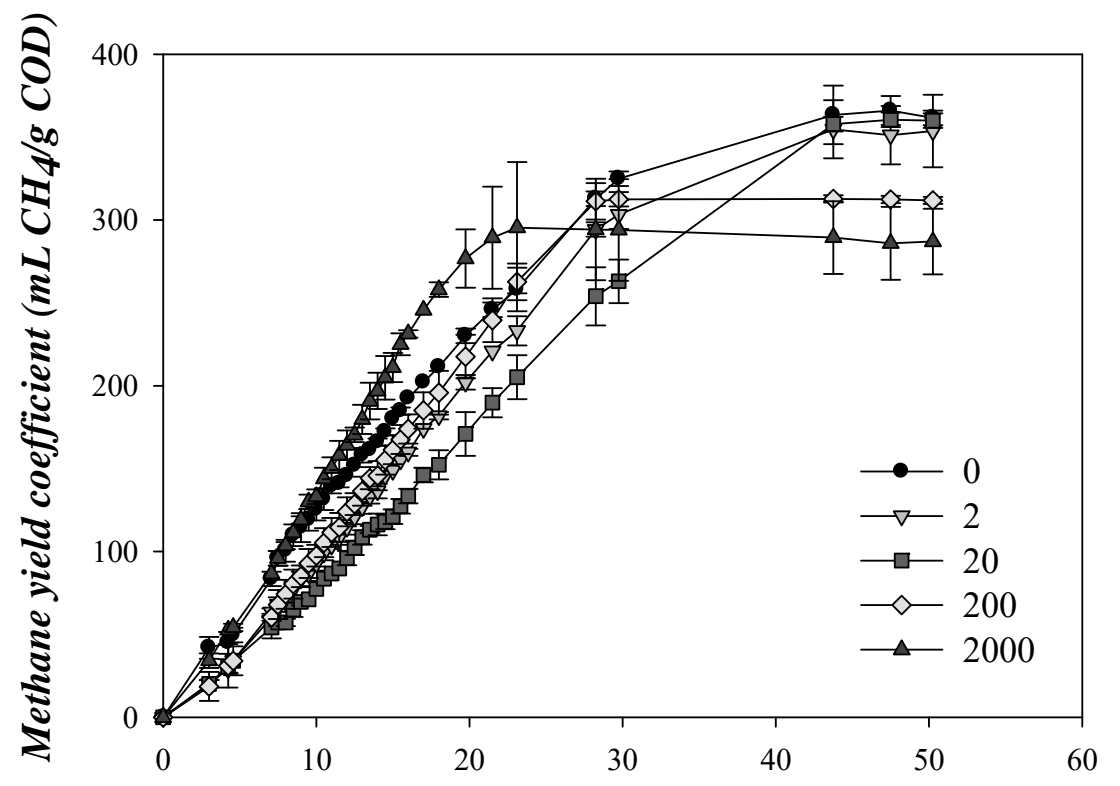

Time (h)

B)

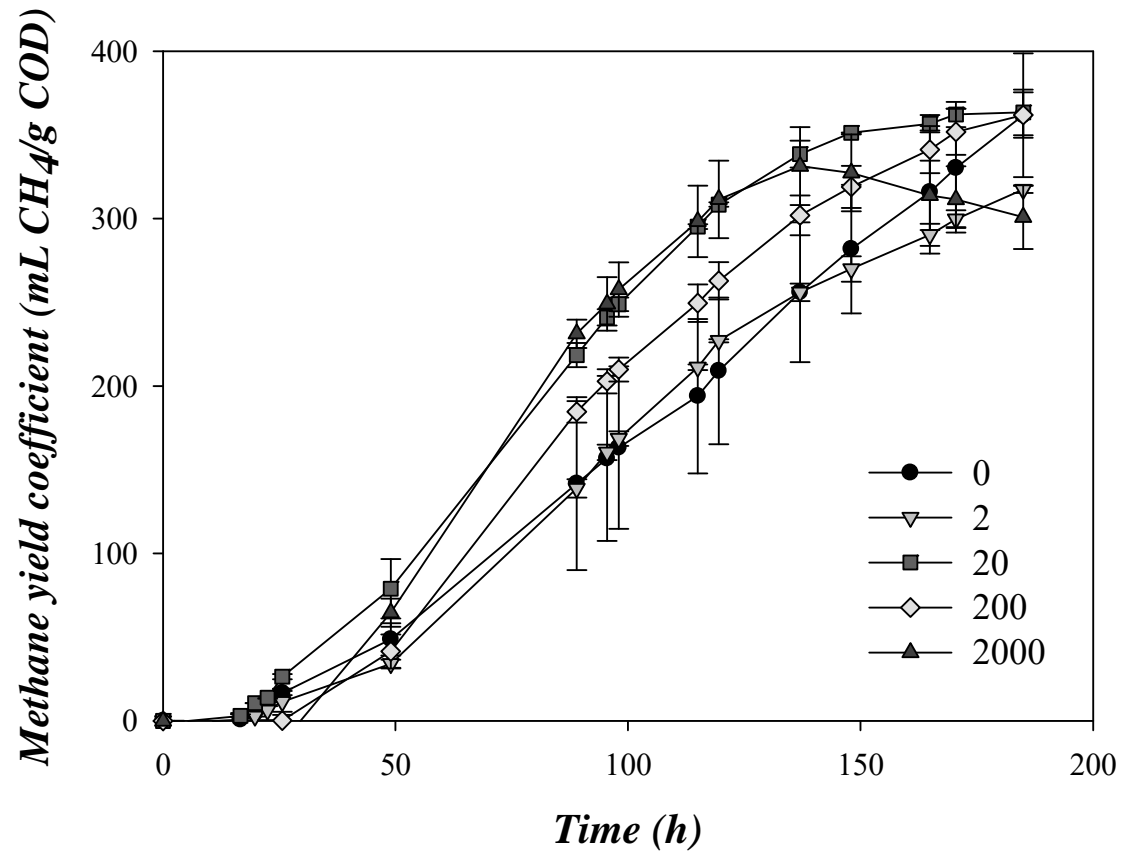


C)

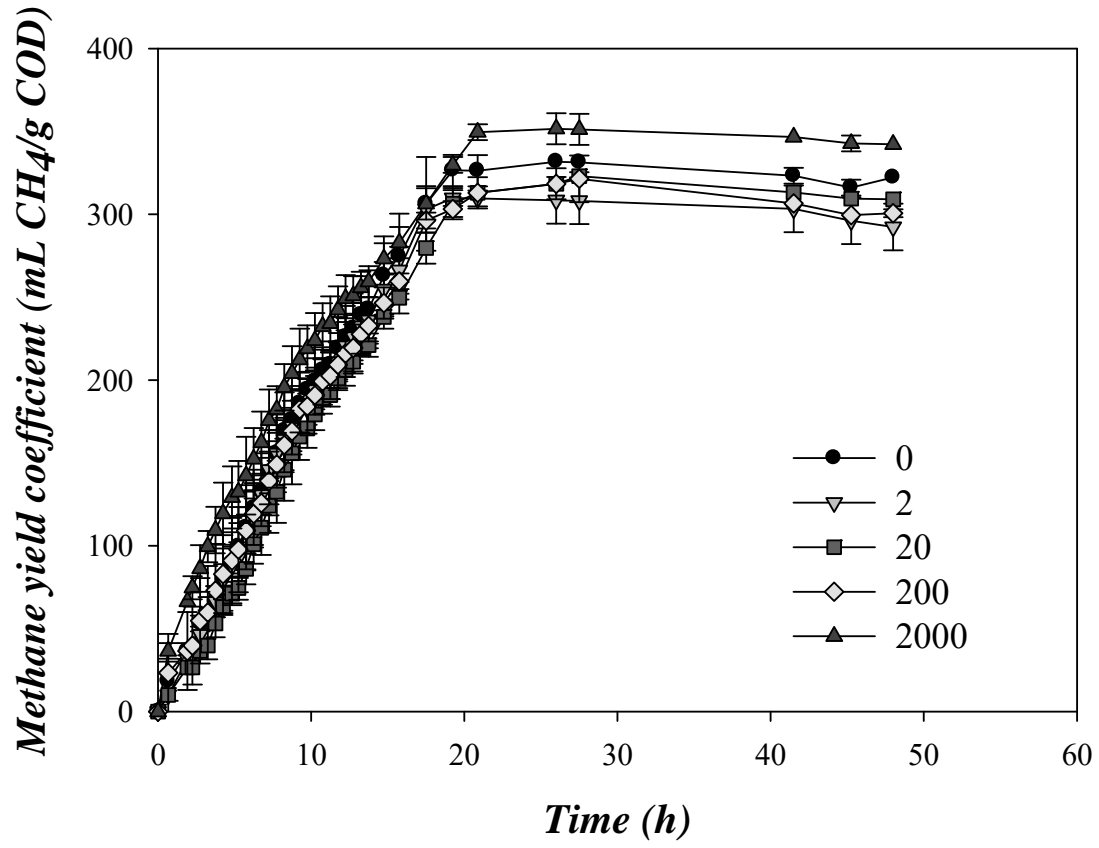

D)

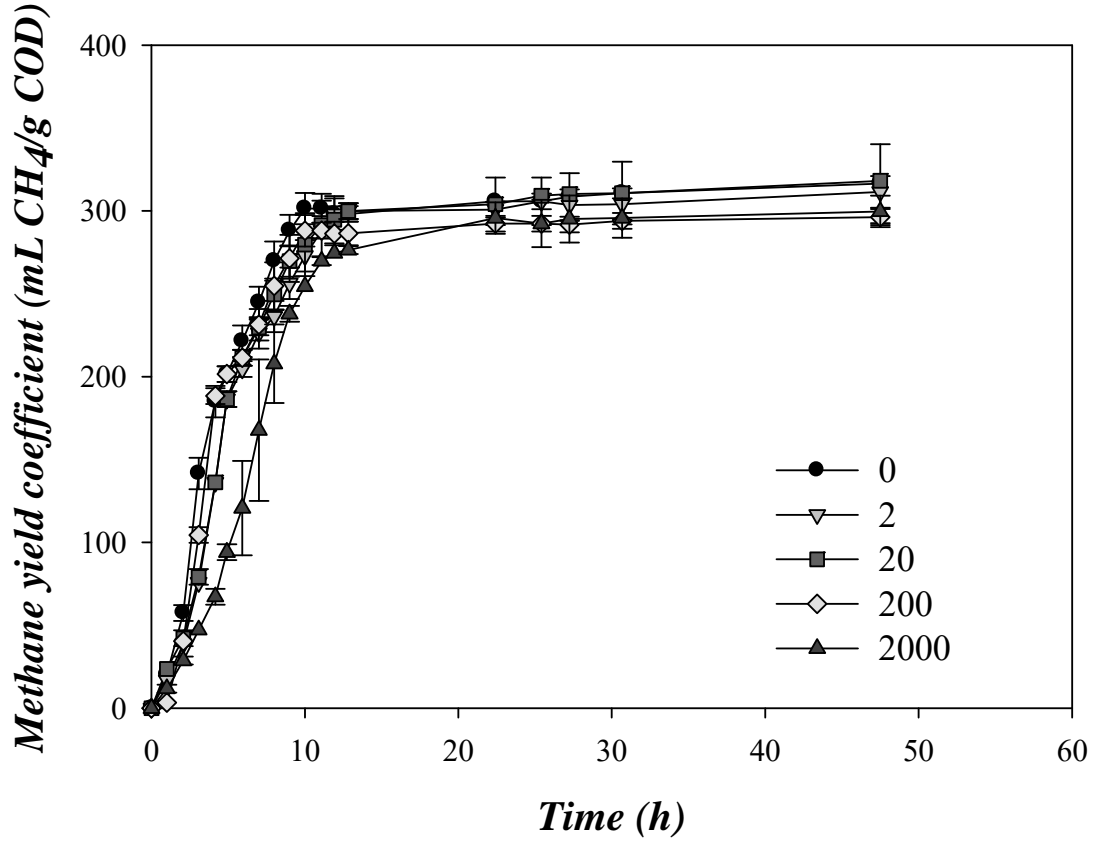


Figure 2.

A)

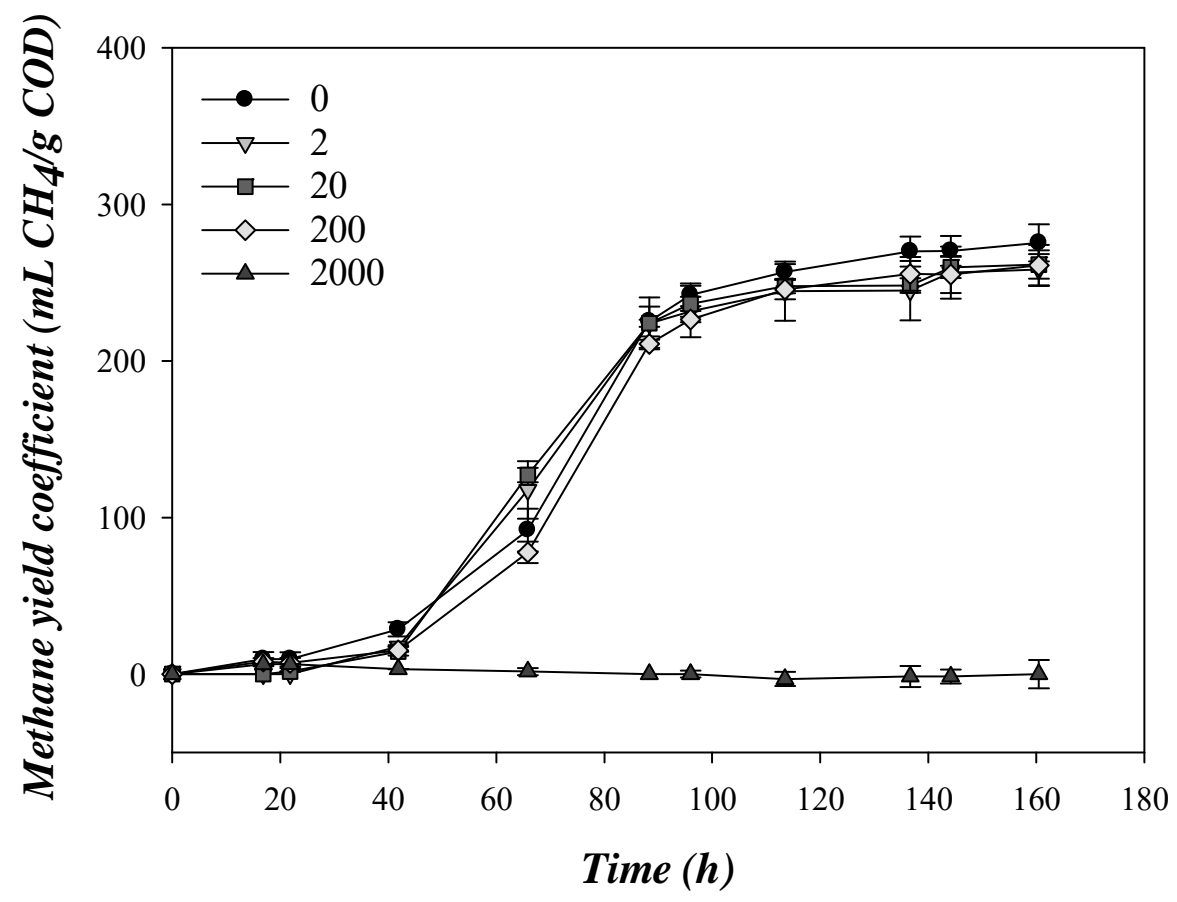

B)

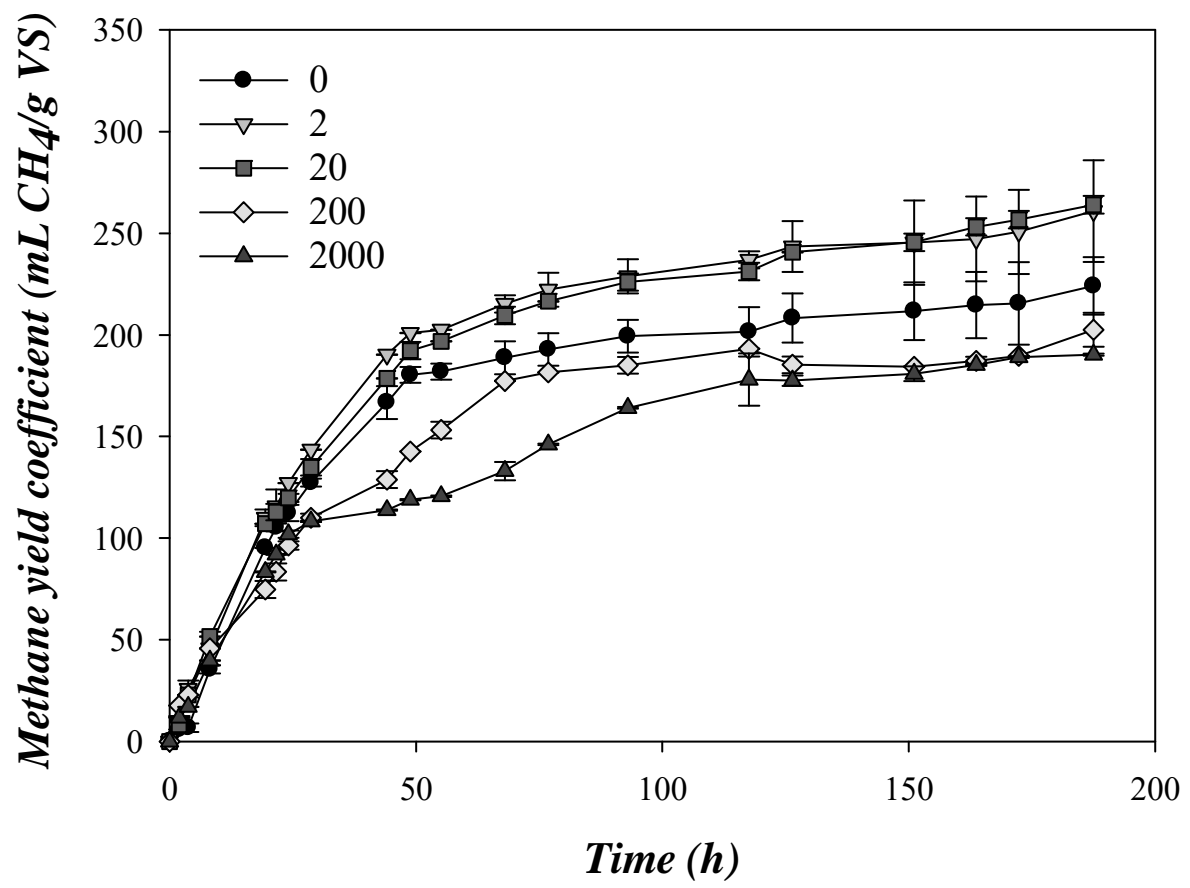


Figure 3.

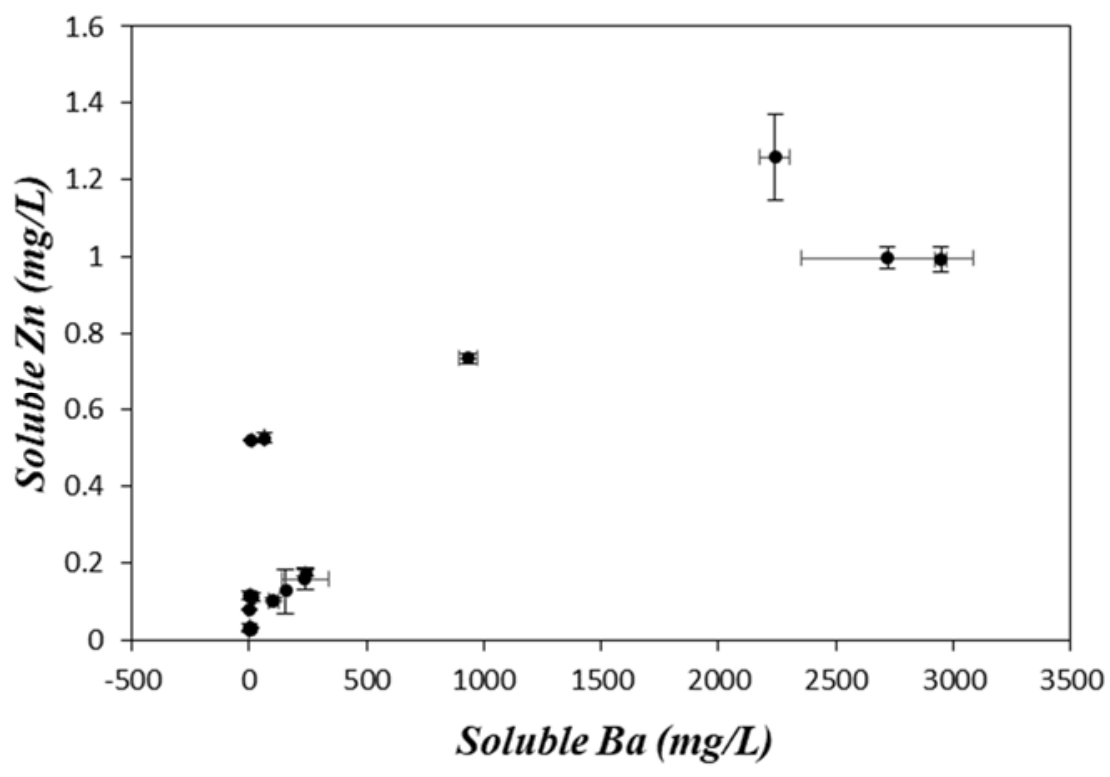


Table 1. Analytical characterization of the inoculum, reagent and the employed substrates

\begin{tabular}{cccccc}
\hline Inoculum & $\mathrm{BaCl}_{2} \cdot \quad$ Cellulose & Glucose & VFA mixture & Acetate & Dried green fodder \\
& $2 \mathrm{H}_{2} \mathrm{O}$ & &
\end{tabular}

\begin{tabular}{|c|c|c|c|c|c|c|c|}
\hline TS (g/kg) & $29.1 \pm 2.7$ & n.a & $969.1 \pm 1.7$ & $999.2 \pm 0.1$ & n.a & $981.9 \pm 1.9$ & $895.9 \pm 1.6$ \\
\hline VS (g/kg) & $18.1 \pm 1.6$ & n.a & $943.4 \pm 1.4$ & $999.2 \pm 0.1$ & n. $a$ & $981.9 \pm 1.9$ & $804.7 \pm 4.7$ \\
\hline Alkalinity $\left(\mathrm{mg} \mathrm{CaCO}_{3} / \mathrm{L}\right)$ & $3352 \pm 920$ & n.a & n.a & n. $a$ & n. $a$ & n.a & n. $a$ \\
\hline pH & $7.9 \pm 0.2$ & n.a & n.a & n.a & n.a & n.a & n.a \\
\hline Ba (mg/kg TS) & $52.8 \pm 5.1$ & $>2000$ & n.a & n.a & n.a & n.a & $49.7 \pm 0.1$ \\
\hline Co $(\mathrm{mg} / \mathrm{kg} \mathrm{TS})$ & $5.4 \pm 0.5$ & $<0.002$ & n.a & n.a & n. $a$ & n.a & $4.9 \pm 0.1$ \\
\hline $\mathrm{Cu}(\mathrm{mg} / \mathrm{kg} \mathrm{TS})$ & $57.1 \pm 4.5$ & 0.205 & n.a & n.a & n.a & n.a & $55.6 \pm 0.1$ \\
\hline $\mathrm{Fe}(\mathrm{mg} / \mathrm{kg} \mathrm{TS})$ & $5751.6 \pm 6.4$ & $<0.02$ & n.a & n.a & n.a & n.a & $5478.2 \pm 0.1$ \\
\hline Ni (mg/kg TS) & $42.0 \pm 2.1$ & $<0.005$ & n.a & n.a & n.a & n.a & $39.7 \pm 0.1$ \\
\hline$S(\mathrm{mg} / \mathrm{kg} \mathrm{TS})$ & $8089 \pm 733$ & n.a & n.a & n.a & n.a & n.a & $7826.4 \pm 0.1$ \\
\hline $\mathrm{Zn}(\mathrm{mg} / \mathrm{kg} \mathrm{TS})$ & $377.9 \pm 15.3$ & 0.789 & n.a & n. $a$ & n.a & n.a & $378.9 \pm 0.1$ \\
\hline
\end{tabular}

n.a., not available 
1 Table 2. Composition of macronutrients and micronutrients solutions

\begin{tabular}{llc}
\hline & $\mathrm{NH}_{4} \mathrm{Cl}(\mathrm{mg} / \mathrm{L})$ & 1400 \\
& $\mathrm{~K}_{2} \mathrm{HPO}_{4}(\mathrm{mg} / \mathrm{L})$ & 1250 \\
Macronutrients & $\mathrm{MgSO}_{4} \cdot 7 \mathrm{H}_{2} \mathrm{O}(\mathrm{mg} / \mathrm{L})$ & 500 \\
& $\mathrm{CaCl}_{2} \cdot 2 \mathrm{H}_{2} \mathrm{O}(\mathrm{mg} / \mathrm{L})$ & 50 \\
& $\mathrm{Yeast}_{(\mathrm{mg} / \mathrm{L})}$ & 500 \\
\hline & $\mathrm{FeCl}_{2} \cdot 4 \mathrm{H}_{2} \mathrm{O}(\mu \mathrm{g} / \mathrm{L})$ & 2000 \\
& $\mathrm{CoCl}_{2} \cdot 6 \mathrm{H}_{2} \mathrm{O}(\mu \mathrm{g} / \mathrm{L})$ & 5000 \\
& $\mathrm{MnCl}_{2} \cdot 4 \mathrm{H}_{2} \mathrm{O}(\mu \mathrm{g} / \mathrm{L})$ & 50 \\
& $\mathrm{AlCl}_{3} \cdot 6 \mathrm{H}_{2} \mathrm{O}(\mu \mathrm{g} / \mathrm{L})$ & 50 \\
& $\left(\mathrm{NH}_{4}\right) 6 \mathrm{Mo}_{7} \mathrm{O}{ }_{24} \cdot 4 \mathrm{H}{ }_{2} \mathrm{O}(\mu \mathrm{g} / \mathrm{L})$ & 50 \\
& $\mathrm{H}_{3} \mathrm{BO}_{3}(\mu \mathrm{g} / \mathrm{L})$ & 50 \\
& $\mathrm{ZnCl}_{2}(\mu \mathrm{g} / \mathrm{L})$ & 50 \\
& $\mathrm{CuCl}_{2} \cdot 2 \mathrm{H}_{2} \mathrm{O}(\mu \mathrm{g} / \mathrm{L})$ & 50 \\
\hline
\end{tabular}

2

3 
4 Table 3. Concentration of soluble metals in the assays at the end of the BMP. Mo and Se 5 were not detected in any case and, therefore, are not shown.

\begin{tabular}{|c|c|c|c|c|c|c|c|}
\hline \multirow[b]{2}{*}{ Substrate } & \multirow[b]{2}{*}{ Ba added } & \multicolumn{6}{|c|}{ Soluble metals } \\
\hline & & $\mathbf{B a}$ & $\mathrm{Cu}$ & Zn & $\mathrm{Fe}$ & Co & $\mathbf{N i}$ \\
\hline & $\mathrm{mg} / \mathrm{L}$ & $\mathrm{mg} / \mathrm{L}$ & $\mu \mathrm{g} / \mathrm{L}$ & $\mu \mathrm{g} / \mathrm{L}$ & $\mu \mathrm{g} / \mathrm{L}$ & $\mu \mathrm{g} / \mathrm{L}$ & $\mu g / L$ \\
\hline \multirow{5}{*}{ Hydrogen } & $\mathbf{0}$ & $0.6 \pm 0.2^{*}$ & $42.4 \pm 0.8$ & $87.3 \pm 2.9$ & $689.3 \pm 5.8$ & $16.1 \pm 4.7$ & $73 \pm 40$ \\
\hline & 2 & $0.4 \pm 0.1 *$ & $56.7 \pm 0.4$ & $185.4 \pm 8.1$ & $1740 \pm 20$ & $22.3 \pm 9.8$ & $145 \pm 12$ \\
\hline & 20 & n.a. & n.a. & n.a. & n.a. & n.a. & n.a. \\
\hline & 200 & $17.7 \pm 0.7$ & n.d & $947 \pm 81^{*}$ & $5504 \pm 102$ & $388 \pm 114^{*}$ & $700 \pm 140^{*}$ \\
\hline & 2000 & $65.4 \pm 0.8$ & $170.7 \pm .2 .9$ & $525 \pm 12$ & $2285 \pm 41.6$ & $20 \pm 12$ & $146 \pm 9.7$ \\
\hline \multirow{5}{*}{ Acetate } & $\mathbf{0}$ & $0.22 \pm 0.02 *$ & $5.8 \pm 0.6$ & $31 \pm 18^{*}$ & $1490 \pm 543$ & $6.5 \pm 1.3$ & $15 \pm 7^{*}$ \\
\hline & 2 & $1.4 \pm 0.1$ & $32 \pm 15$ & $113 \pm 11$ & $3610 \pm 57$ & $8.3 \pm 0.7$ & $26 \pm 3 *$ \\
\hline & 20 & $6.5 \pm 0.1$ & $2.9 \pm 0.1$ & $28.9 \pm 0.9$ & $382 \pm 353$ & $7.1 \pm 0.3^{*}$ & $15 \pm 4 *$ \\
\hline & 200 & $239.5 \pm 3.2$ & $130 \pm 4$ & $171 \pm 9$ & $1083 \pm 682$ & $5.7 \pm 2.7^{*}$ & $29 \pm 2$ \\
\hline & 2000 & $353.6 \pm 3.1$ & n.d & $161 \pm 18^{*}$ & $1861 \pm 2498$ & $5.9 \pm 0.4$ & $80 \pm 2 *$ \\
\hline \multirow{5}{*}{ VFA mixture } & $\mathbf{0}$ & n.d & $11.8 \pm 0.3$ & $30 \pm 10$ & $2065 \pm 2095$ & $6.1 \pm 0.6$ & $18 \pm 3^{*}$ \\
\hline & 2 & n.d & $17 \pm 18$ & $25.5 \pm 0.6$ & $3443 \pm 4355$ & $22 \pm 22 *$ & $42 \pm 4 *$ \\
\hline & 20 & $9.8 \pm 1.4$ & $19 \pm 18$ & $518.0 \pm 2.1$ & $1150 \pm 1136$ & $6.4 \pm 0.4$ & $16 \pm 2$ \\
\hline & 200 & $154.5 \pm 1.9$ & $27.3 \pm 2.7$ & $126 \pm 56$ & $2135 \pm 301$ & $5.9 \pm 0.1^{*}$ & $9 \pm 1$ \\
\hline & 2000 & $2720 \pm 367$ & $4.51 \pm 0.03$ & $998 \pm 27$ & $875 \pm 726$ & $5.5 \pm 0.4$ & $12 \pm 5^{*}$ \\
\hline \multirow{5}{*}{ Glucose } & $\mathbf{0}$ & n.d & $15 \pm 12$ & $79.9 \pm 2.5$ & $1925 \pm 92$ & $6.1 \pm 0.3$ & $17 \pm 1^{*}$ \\
\hline & 2 & $0.4 \pm 0.3 *$ & $20 \pm 23$ & $44 \pm 19$ & $6288 \pm 2963$ & $6.2 \pm 0.4^{*}$ & $12 \pm 1 *$ \\
\hline & 20 & $15.5 \pm 0.6^{*}$ & n.d & $25.2 . \pm 0.2$ & $965 \pm 376$ & $4.9 \pm 0.1$ & $39 \pm 44^{*}$ \\
\hline & 200 & $238 \pm 99$ & $16 \pm 13$ & $157 \pm 29$ & $1578 \pm 557$ & $6.7 \pm 0.5$ & $32 \pm 16^{*}$ \\
\hline & 2000 & $2240 \pm 66$ & $7.8 \pm 4.8$ & $1259 \pm 112$ & $891 \pm 892$ & $5.6 \pm 0.1 *$ & $9 \pm 2 *$ \\
\hline \multirow{5}{*}{ Cellulose } & $\mathbf{0}$ & $1.8 \pm 0.3 *$ & $26.0 \pm 6.8$ & $81.5 \pm 3.3$ & $8306 \pm 4587$ & $8.0 \pm 0.1$ & $26 \pm 1 *$ \\
\hline & 2 & $1.9 \pm 0.2 *$ & $3.4 \pm 3.5$ & $35.8 \pm 8.0$ & $513 \pm 144$ & $5.9 \pm 0.4^{*}$ & $9.0 \pm 0.4$ \\
\hline & 20 & $14.9 \pm 6.2$ & $20.7 \pm 0.3$ & $110 \pm 10$ & $1096 \pm 364$ & $5.8 \pm 0.2$ & $23.8 \pm 1.7$ \\
\hline & 200 & $133 \pm 8^{*}$ & $39 \pm 52$ & $195 \pm 125$ & $1279 \pm 1156$ & $6.6 \pm 0.7 *$ & $61.6 \pm 4.2$ \\
\hline & 2000 & $2947 \pm 28$ & $16 \pm 14$ & $993 \pm 32$ & $1081 \pm 679$ & $6.1 \pm 0.5^{*}$ & $31 \pm 2 *$ \\
\hline \multirow{5}{*}{ DGF } & $\mathbf{0}$ & $0.2 \pm 0.1^{*}$ & n.d & $37 \pm 22^{*}$ & $1070 \pm 576$ & $8.1 \pm 0.3$ & $25 \pm 10^{*}$ \\
\hline & 2 & $0.6 \pm 0.1^{*}$ & $92.1 \pm 1.7$ & $17 \pm 11^{*}$ & $1140 \pm 198$ & $8.4 \pm 0.5$ & $18 \pm 3 *$ \\
\hline & 20 & $7.2 \pm 0.5$ & $2.67 \pm 0.04$ & $33.0 \pm 1.6$ & $4550 \pm 3895$ & $9.38 \pm 0.03$ & $23 \pm 1 *$ \\
\hline & 200 & $103 \pm 19$ & $2.49 \pm 0.05$ & $102.2 \pm 5.4$ & $1322 \pm 1005$ & $10.7 \pm 1.1$ & $15.7 \pm 1.3$ \\
\hline & 2000 & $932 \pm 41$ & $10.6 \pm 0.6$ & $736 \pm 13$ & $446 \pm 57.9$ & $13.3 \pm 0.2$ & $42 \pm 34^{*}$ \\
\hline
\end{tabular}

$6 \quad$ n.d., not detected

7 n.a., not available

$8 \quad$ Values marked with * should be taken with care due to an increased standard deviation. 


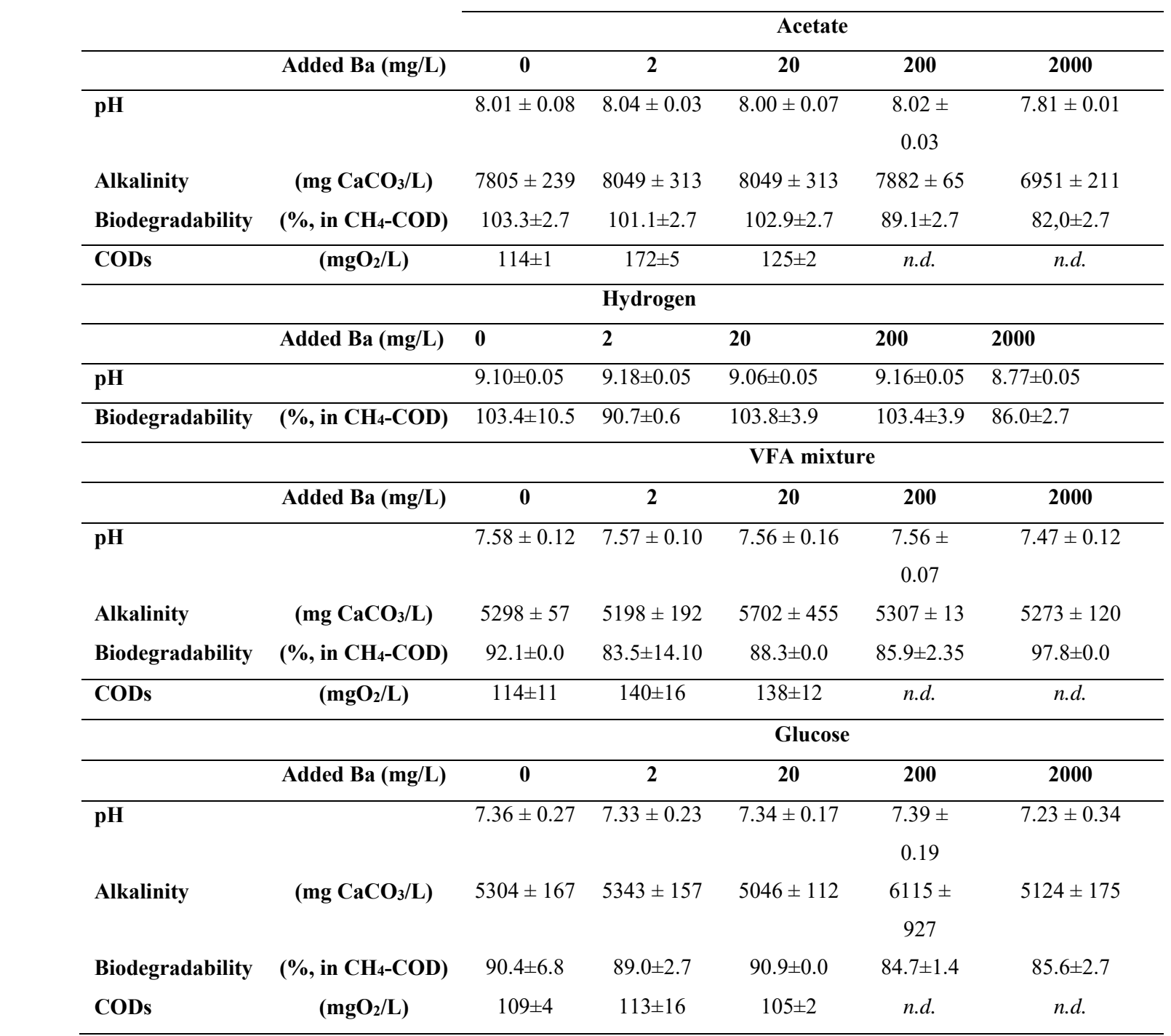

Table 4. $\mathrm{pH}$, Alkalinity (mg $\mathrm{CaCO}_{3} / \mathrm{L}$ ), biodegradability (\%), and soluble COD (CODs; mg $\mathrm{O}_{2} / \mathrm{L}$ ), in the BMP tests for acetate, hydrogen, VFA mixture and glucose at the end of the experiment.

n.d., not detected 
Table 5. $\mathrm{pH}$, Alkalinity (mg $\left.\mathrm{CaCO}_{3} / \mathrm{L}\right)$, biodegradability (\%), and COD soluble ( $\left.\mathrm{mg} \mathrm{O}_{2} / \mathrm{L}\right)$, in the BMP tests for cellulose and DGF at the end of the experimental time.

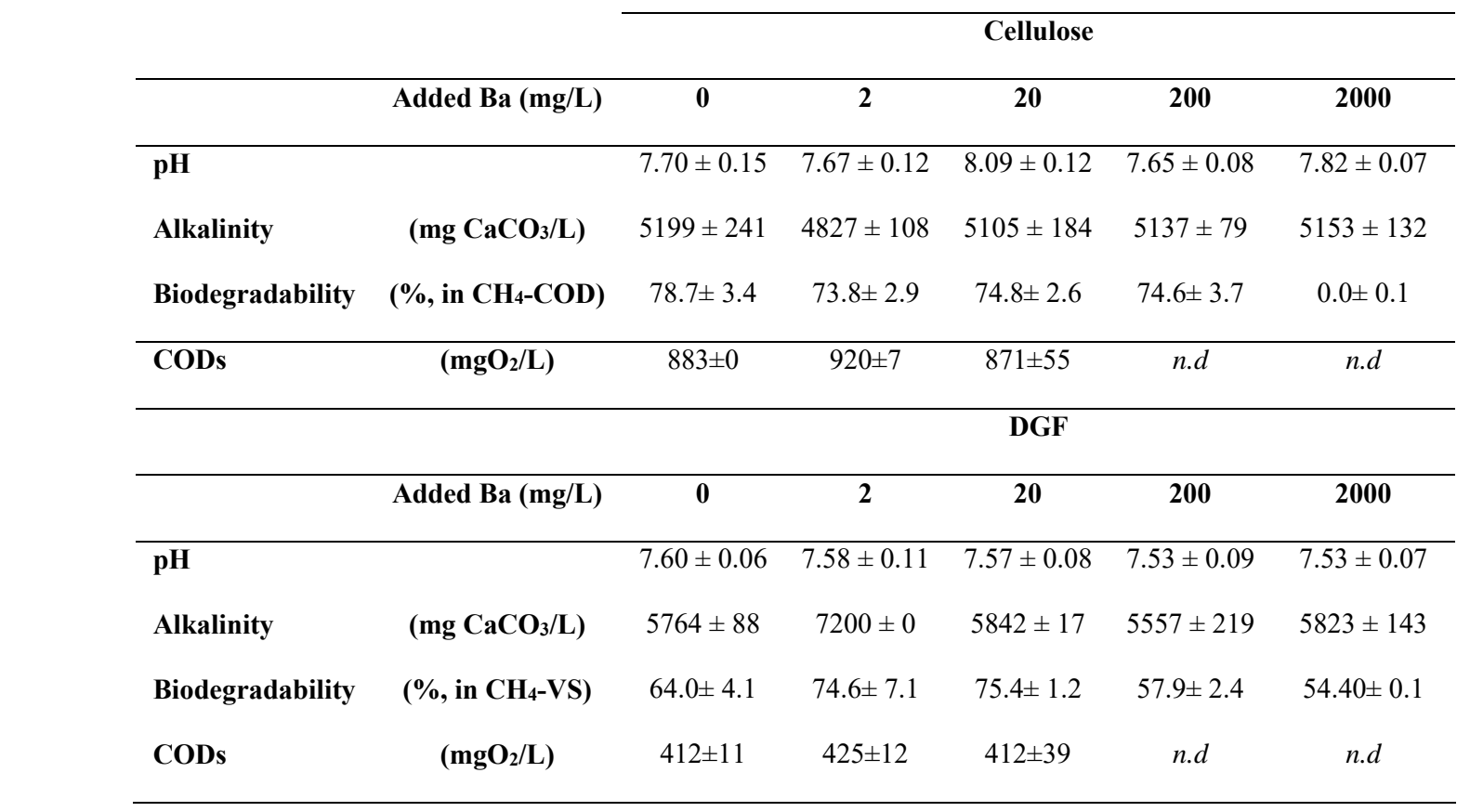

n.d., not detected 
Table 6. Kinetics parameters obtained from the transfer function applied to the BMP tests of dried green fodder (DGF). $\sigma_{\text {est, }}$ standard error of estimate.

\begin{tabular}{lccccc}
\hline Added Ba & $\mathbf{0}$ & $\mathbf{2}$ & $\mathbf{2 0}$ & $\mathbf{2 0 0}$ & $\mathbf{2 0 0 0}$ \\
\hline $\boldsymbol{G}_{\max }(\mathbf{m L} / \mathbf{g ~ V S})$ & 214.7 & 250.2 & 253.1 & 195.6 & 184.1 \\
$\boldsymbol{R}_{\boldsymbol{m}}(\mathbf{m L} /(\mathbf{g V S} \cdot \mathbf{d}))$ & 7.10 & 7.59 & 6.83 & 5.45 & 4.61 \\
$\boldsymbol{\lambda}(\mathbf{d})$ & $1.40 \pm 0.47$ & $0.50 \pm 0.38$ & $0.06 \pm 0.48$ & $4.87 \mathrm{E}-09 \pm 0.70$ & $2.80 \mathrm{E}-10 \pm 1.09$ \\
$\mathbf{r}^{2}$ & 0.9946 & 0.9971 & 0.9964 & 0.9913 & 0.9717 \\
$\boldsymbol{\sigma}_{\text {est }}$ & 6.07 & 5.02 & 5.59 & 6.61 & 11.00 \\
Error $(\%)$ & 4.2 & 4.1 & 4.1 & 3.5 & 3.3 \\
\hline
\end{tabular}

22 